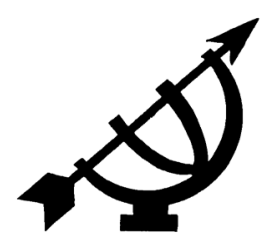

\title{
The mythic foundation of National Socialism and the contemporary claim that the Nazis were Christians
}

\author{
I. Hexham
}

Department of Religious Studies

University of Calgary

CALGARY Canada

E-mail: hexham@ucalgary.ca

\begin{abstract}
The mythic foundation of National Socialism and the contemporary claim that the Nazis were Christians

This article examines the ideas of Alfred Rosenberg, the "chief ideologue" of German National Socialism. Its aim is to show that, contrary to the claims of a growing number of people encouraged by the so-called "new atheism", the Nazis held a coherent worldview that was vehemently anti-Christian. To deal with criticism of Christianity by these writers and speakers, it is necessary for Christians to become aware of the Nazi worldview and how deeply it was rooted in modern paganism.
\end{abstract}

\section{Opsomming}

Die mitiese grondslag van Nasionale Sosialisme en die kontemporêre bewering dat die Nazi's Christene was

Hierdie artikel ondersoek die idees van Alfred Rosenberg, die "hoof-ideoloog" van die Duitse Nasionale Sosialisme. Die doel van hierdie artikel is om aan te toon dat, in teenstelling met die bewerings van 'n groeiende aantal persone aangemoedig deur die sogenaamde "nuwe ateïsme", die Nazi's 'n samehangende wêreldbeskouing gehuldig het wat radikaal anti-Christelik was. Hierdie standpunt word verdedig. Ten einde hierdie skrywers en sprekers se kritiek teenoor die Christendom verantwoordelik te hanteer, moet Christene bewus wees van die Nazi-wêreldbeskouing en die diep verworteling daarvan in die moderne paganisme. 


\section{Introduction}

According to Steigmann-Gall (2003) National Socialism was essentially a Christian movement. Earlier commentators, he contends, wrongly assumed that at its core National Socialism was an antiChristian form of neo-paganism, because they failed to distinguish between anti-clericalism and the rejection of Christianity itself. They also failed to recognise that although there were some people he identifies as "paganists" in the movement, they were marginal and to a considerable degree Christians in the core of their thinking (Steigmann-Gall, 2003:3-6).

There can be little doubt that, if correct, Steigmann-Gall's work will revolutionise our understanding of both National Socialism and Christianity. What follows is an examination of the arguments and beliefs of the key Nazi thinker, Alfred Rosenberg, who SteigmannGall dismisses by citing the English translation of Bracher's book, Die deutsche Diktatur (1969). In the translation of 1970 Rosenberg is described as "the administrative clerk of National Socialist ideology" (Steigmann-Gall, 2003:91; cf. Bracher, 1970:281).

The problem here is that, although this line is quoted correctly, the English translation misinterpreted the German original where Rosenberg is described as "der Weltanschauungsprokurist des Nationalsozialismus" (Bracher, 1969:307). This is more accurately translated to "worldview authority" or "the executive secretary of the National Socialist worldview". Either of these translations, or any of the possible alternatives, bestow a far higher status on Rosenberg within Nazism than is suggested by the misleading translation "administrative clerk".

Further, Steigmann-Gall takes Bracher's argument out of context, even as it is presented in the English translation. Bracher (1970:281282) concludes about Rosenberg.

At the end ... Rosenberg's widely distributed pseudo bible, became a terrible reality. Whether he was actually read or taken seriously as a philosopher, Rosenberg has no reason to be disappointed ... the regime did everything in its power to realize his bizarre ideology ... he contributed more than any of the old and new fighters to the pseudo-scientific and pseudo-religious justification of these power politics ...

Since I have already dealt with Steigmann-Gall's highly misleading text (Hexham, 2007), no further discussion is needed here. Instead, what is presented is a systematic account of Rosenberg's worldview 
and its promotion of neo-paganism as the core of National Socialism.

\section{The motivating forces of National Socialism}

To understand the motivating forces that drove Nazism, it is necessary to set aside crude representations of Nazism to recognise that the movement was led by intellectuals driven by deep seated commitments. It is also necessary to recognise that the Nazi leadership comprised highly sophisticated young intellectuals committed to national regeneration through their commitment to a cause. Once these facts are acknowledged, it becomes possible to make sense of Nazi literature to understand its inner logic, and to realise that highly educated men and women can commit grotesque crimes through their total commitment to a cause.

Therefore, the starting point for anyone wanting to understand the Nazis is the attempt to understand them in their own terms. To understand the Nazis one must develop empathy with Nazis and begin to see the world the way Nazis saw the world. Such an approach will undoubtedly shock many people. Surely, they will argue, to empathise with Nazis is to develop sympathy for them and thus exonerate their crimes. Nothing could be further from the truth. Developing empathy does not mean sympathising. It means the developing of the ability to see things as other people see them. However, if one lacks a firm morality and draws back from condemning Nazi crimes as evil, empathy can develop into sympathy. After all, as the Russian writer Dostoyevsky points out in his great novel, The brothers Karamazov, "if God is dead everything is permitted" (Dostoyevsky, 1995:52). Therefore, for the morally hesitant, empathy may be dangerous. However, as an academic method, it is unrivalled and the only way one can ever begin to understand the past.

\section{Importance of propaganda}

Like Marx, Lenin, and Gramachi, all of whom had very definite ideas about the importance of creating small party elites, Hitler also developed a clear theory about the need for a small, tightly knit party that would change the world. In this process, propaganda was to play a key role. In Mein Kampf he writes:

If a movement has the intention of pulling down a world and of building a new one in its place, then there must be absolute clarity about the following points in the ranks of its own leaders: 
Every movement, at first, will have to divide the human material it has won into two groups: into followers and members.

The task of propaganda is to attract followers; the taks of organization to win members.

A follower of a movement is one who declares himself in agreement with its aims; a member is one who fights for it ... there will be at least ten followers for every one or two members at most ...

The first task of propaganda is the winning of people for the future organization; the first task of the organization is the winning of people for the continuation of propaganda. The second task of propaganda is the destruction of the existing condition and the permeation of this condition with the new doctrine, while the second task of the organization must be the fight for power, so that by it, it will achieve the final success of the doctrine.

The most striking success of the revolution of a view of life will always be won whenever the new view of life is, if possible, taught to all the people, and if necessary, is later forced upon them, while the organization of the idea, that means the movement, has to embrace only so many people as absolutely necessary for the occupation of the nerves centres of the State involved. (Hitler, 1941:849-852; cf. Hitler, 1940:651-655.)

This rather long passage is crucial for understanding the relationship between Hitler and Rosenberg, whom he appointed as his chief theoretician in charge of propagating the Weltanschauung (or worldand life view) of the movement, while Joseph Goebbels directed his day to day propaganda aimed at securing power.

\section{Hitler and Rosenberg's Myth}

Most of what we know about Hitler's attitude towards Rosenberg's writings comes from anecdotal comments by people who knew him. While some reports are contradictory, a surprising number of observers from many different backgrounds and ideological positions commented on the widespread interest in, and acceptance of Rosenberg's ideas by Hitler. Strasser claimed that during a meeting early in 1928, Hitler told him the following.

'The ideology of Rosenberg is an inalienable component of National Socialism', he shouted stressing every syllable ... 'At the moment, Christianity is one of the points of the party program as I formulated it. But, one must look beyond. Rosen- 
berg is a forerunner, a prophet - his theories are the expression of the German soul.' (Strasser, 1948:125.)

Similarly, Ludecke (1937), an early confidant of Hitler, records this exchange with him:

'You haven't met Rosenberg yet?' Hitler asked me abruptly. I replied that I knew him but slightly. 'You must get to know him better, get on good terms with him. He is the only man whom I always listen to. He is a thinker.'

Then Ludecke adds:

Rosenberg, the twenty-five year old Baltic German, became Hitler's closest thinker, and more than anybody else, in his later writings, shaped the Nazi 'Weltanschauung' - a word somewhat inadequately translated 'world-outlook'. (Ludecke, 1937:79, 84.)

Another early Hitler confidant, Hanfstaengl, later claimed that Hitler "was deeply under the spell of Rosenberg" (Hanfstaengl, 1994:41).

Of course it is possible to question the accuracy of all of these people and point out that at times Hitler distanced himself from Rosenberg. People who are tempted to do so, need to remember that Hitler was a master of deception who told people what they wanted to hear. Therefore, when confronted by church leaders who were concerned about the implications of Rosenberg's views, including his strident anti-Semitism, Hitler distanced himself and the Party from Rosenberg, describing him as a private individual.

Nevertheless, it seems clear that Hitler had no doubts about Rosenberg's value as a theoretician. Two key pieces of documentary evidence provide direct information about Hitler's personal attitude towards Rosenberg. First, he was the first recipient of the National Prize for Art and Science. The official citation, approved by Hitler and read by Goebbels to a mass meeting at the 1937 Party Congress, states:

Alfred Rosenberg distinguished himself because he helped establish and stabilize the worldview of National Socialism both scientifically and intuitively. He especially distinguished himself because he fought untiringly to maintain the purity of the National Socialist worldview. (Schmitt, 1937:49 ff.)

Secondly, in a personal letter sent by Hitler to Rosenberg on his 50th birthday in 1943, Hitler wrote: 
I still remember the day when I met you in the home of Dietrich Eckart. Since then you became the first spiritual and intellectual co-builder of the party. One day history will record how much you did to clarify and stabilize the worldview foundations of the movement ... you are one of the most distinguished human personalities that Fate has granted me to meet. (Hitler, 1943.)

No doubt Hitler was uncomfortable with Rosenberg's personality and was prepared to distance himself publicly from Rosenberg's views when it served his purpose. It is also true that he made snide remarks about him to some party colleagues. Nevertheless, these two documents, both of which were dictated by Hitler when he could easily have sidelined Rosenberg, show a remarkable appreciation of his ideas and role in creating the Party's Weltanschauung.

\section{Rosenberg and the Nazi leadership}

Nazi leaders were intensely jealous of each other and often made cutting remarks about their rivals. Therefore, it is easy to find numerous quotations by people criticising Rosenberg. Thus, Goebbels could garbage his Mythus when it suited him. Yet, as his diary (Tagesbücher) shows, Goebbels' attitude was far more complex. Early in his career he expressed admiration for Rosenberg writing "I quite like him, especially because he is so relevant." (Goebbels, 1987:356.) Later he writes:

Evening with Rosenberg to his talk. He spoke fabulously. Full of lashing coldness. Rosenberg really is a brain. Perhaps the opposite of me, but he impresses me. (Goebbels, 1987:363.)

Then he said: "Rosenberg is a Baltic fox. At the same time, very intelligent and ambitious." (Goebbels:1987:498.) This remark was made even though earlier he said "Rosenberg is my deadly enemy ..." (Goebbels:1987:502). Nevertheless, he decided to study the Mythus carefully, writing "Reading: The myth of the 20th C by Rosenberg. I believe, very good, have to immerse myself." (Goebbels:1987:611.).

Thirdly, Albert Speer and other Nazi leaders gave evidence during their war crimes trials that Hitler had nothing but contempt for Rosenberg (Speer, 1970:109-110). Such evidence is worthless, because Allied and later German prosecutors used Rosenberg's Mythus to show that the defendants were influenced by genocidal ideas. Therefore, few were prepared to admit reading the book and no German who could possibly stand trial for war crimes was going 
to admit that they were influenced by Rosenberg's ideas or his Mythus.

Speer, who was notoriously unreliable (Gitta, 1995), cast doubt on the truth of his own claim that Hitler had no interest in "mysticism" when he wrote that Hitler commissioned him to design a great hall that was intended to serve as the spiritual and physical center of the new Berlin planned by Hitler. He writes:

This structure, the greatest assembly hall in the world ever conceived up to that time, consisted of one vast hall that could hold between 150,000 and 180,000 persons standing ... the hall was essentially a place of worship. The idea was that over the course of centuries, by tradition and venerability, it would acquire an importance similar to that of St. Peter's in Rome has for Catholic Christendom. (Speer, 1970:167.)

Why would Hitler plan a new place of worship to rival St. Peter's in Rome? If he indeed planned such a building, is it conceivable that he never discussed it's religious purpose and his own views about religion with Speer?

\section{Rosenberg and ordinary Germans}

Many observers of Germany in the 1920s and 1930s came away convinced that Rosenberg's Mythus was hugely influential. These writers include Dodd, a journalist and daughter of the American Ambassador (Dodd, 1940:241); Kneller, an American Ph.D. student writing on German Education (Kneller, 1941:194 ff.); De Rougemont, a French university professor teaching in Frankfurt-am-Main (De Rougemont, 1998:75); Heuss, who later became State President of the Bundesrepublik (Heuss, 1968:109); Klemperer, a Jewish professor of Romance languages and literatures (Klemperer, 1995:291, 318,385 ), and Hoess, the former Commandant of Auschwitz (Gilbert, 1947:267). The German-Jewish philosopher Löwith also commented on Rosenberg's influence upon German students and even claimed that he discovered that Rosenberg's work was popular among Japanese Nationalists (Löwith, 1986:11, 118). Further, despite his attempt to distance himself from Rosenberg's Der Mythus des 20. Jahrhunderts (1930), Speer (1970:110) confirmed that "the public regarded the book as the standard text for party ideology ...", while Wright (1974:89) points out that a study of "the Nazi press" commissioned by a church group "showed that Rosenberg's views were more widely held in the party than Hitler's". 
Of course, it is possible to discredit each of these writers by questioning the reliability of their individual observations. Thus, support for the view that Rosenberg exercised great influence within both the National Socialist movement and German society, dies a death by a thousand qualifications. Taken together, however, such testimonies present a remarkably unified picture from a wide spectrum of opinions and circumstances over many years.

Equally important is the fact that Hutchinson has meticulously documented a mass of evidence to show that Rosenberg exercised considerable influence over German intellectual life and popular belief during the National Socialist era. This includes Rosenberg's personal travel itinerary involving numerous speeches to crowds of up to 100000 , frequent newspaper reports proclaiming him the intellectual spokesperson of National Socialism, and a large collection of letters from individuals expressing gratitude for his work, especially his Mythus. Letters and other documents show that at times top National Socialist leaders Bormann, Frick, Frank, Goebbels, Hess, Himmler, Ley, Schirach, and Göring, praised and promoted Rosenberg's work while soliciting his support (Hutchinson, 1977:33-58).

The latter tendency was particularly important in the formative years of the Hitler Youth. Rosenberg, as prophet of a new Der Mythus des 20. Jahrhunderts became the liaison between the Hitler Youth and the dozens of völkisch youth groups. Thus already in the 1920s, Rosenberg's influence reached far beyond the Party into the religioracial völkisch movement (Brandenburg, 1968:61, 74-75). The fact that most of these people had disputes with Rosenberg, could criticise, ridicule, and distance themselves from him, does nothing to change the reality that from the beginning until the end of the Party's power they acknowledged him as the main theorist of National Socialism (Kellog, 2005:267-268).

Further evidence demonstrating the popularity of Rosenberg's ideas is found in the impressive sales figures of Rosenberg's Mythus, which became a runaway best seller long before Hitler's election victory in 1933. When the book appeared in 1930 it was said to have caused "a great sensation" (Hüffmeier, 1935) and went through seven editions before Hitler's election victory in 1933. After that sales of the Mythus increased, until it sold between 1 and 2 million copies by 1945 (Hutchinson, 1977:63). At the same time German observers noted that the Mythus was "being 'devoured' by German students" (Chesterton, 1934:9). Later, in 1935, when Rosenberg responded to critics in his An die Dunkelmänner unserer Zeit (Ro- 
senberg, 1935a) his polemical tract sold 300000 copies in the first month and over 900000 by 1942 (Hutchinson, 1977:63). No wonder after studying the impact of the Mythus, Petzold concludes "hundreds of thousands of copies were circulated and drummed into the heads of new fascist leader recruits through systematic indoctrination" (Petzold, 1983:215).

The truth is, Rosenberg knew exactly which audience to target and why. As he explained in his 1930 Foreword, his Mythus was not composed for those who were firmly rooted in existing faith communities, but for those millions who were unbound and searching for new worldview commitments. To them he offered a new faith based on a new mythology that would create a new type of human being (Rosenberg, 1935b:1-3; cf. Poewe, 2006).

\section{Rosenberg's redemption}

The obstacle encountered when anyone attempts to read Rosenberg's Myth of the twentieth century today, is his numerous references to "blood" and the importance of race in his argument. Although this sounds absurd today, it must be read in the context of the time. When Rosenberg wrote it, the idea of what was known as "scientific racism" was widely accepted throughout the world (Barkan, 1992; Dubow, 1995). Because we now reject such ideas it is easy to forget that when it was first published, his book appeared to be utilising the latest scientific discoveries. Therefore, to appreciate the impact of his work on its original readers, try substituting the words "genetics" and "genetic heritage" for his references to blood and race (Rosenberg, 1935b:21-29). When this is done the book suddenly appears far more reasonable than is usually assumed.

Secondly, to appreciate it's appeal, the reader needs to place the Myth in the context with German philosophy and the study of religion. Books like Löwith's From Hegel to Nietzsche (1964), Mosse's The crisis of German ideology (1964), The nationalization of the masses (1991), and Griffin's Modernism and fascism (2007) are essential background reading. Contrary to most people who dismiss Rosenberg's work as a jumble of incoherent thoughts, his Myth actually draws on a long tradition of writers who were immediately recognisable by well educated readers. These writers included such people as the well respected indologist Paul Deussen (Rosenberg, 1935b:29, 337), the English socialist turned Indian activist Annie Besant (Rosenberg, 1935b:49), the anthropological-philosopher Theodore Lipps and numerous other philosophers and social thinkers (Rosenberg, 1935b:416). 
With the notable exception of Chamberlain, the authors who inspired Rosenberg were leading figures in modern thought. Even Chamberlain, whose The foundations of the twentieth century (1899; 1911) and The Aryan worldview (1905) were unscholarly works, drew his ideas from mainstream scholars and received rave reviews by both the popular press and academics, with people like highly respected theologian Adolf Harnack thinking very highly of Chamberlain's work (Field, 1981:225-316).

The significance of this is that the modern reader cannot simply dismiss Rosenberg as "unreadable" without placing his work in the context of both its immediate setting and the intellectual tradition to which it belonged. Once this is done, the Myth becomes a coherent argument offering Germans a new religion. Rosenberg begins by assuming that both Christianity and Humanism were "buried in the bloody chaos of the Great War" (Rosenberg, 1935b:21). Consequently, it is no longer possible to believe in the Bible as the Word of God, the Trinity, original sin, redemption through the sacrifice of Christ, the deity or Christ, or even the Christian God who is revealed as an Asiatic tyrant (Rosenberg, 1935b:76-79).

Into this situation of chaos, Rosenberg claimed a new Weltanschauung had been born that turned away from absolute and static values to a new dynamic creed based upon a rejection of the type of self-knowledge derived from the Delphic injunction "Know thyself," which he interprets as a ploy by priests to enslave free men (Rosenberg, 1935b:259-260). This new worldview, Rosenberg argues, means recognising that the religious and racial heritage of Europe has been poisoned by Christianity, leading to the degeneration of Nordic peoples (Rosenberg, 1935b:442). Now the isolation of visionaries, like Wagner, has come to an end and a new religion is about to be born from the people themselves (Rosenberg, 1935b:443).

By rejecting the Christian degradation of humankind and throwing out the teachings of St. Paul which were "shaped by Judaism" and intended "to spiritually turn us into Jews", a new beginning is possible. Consequently, all free people must rid themselves of "the so called old testament" (Rosenberg, 1935b:602-603).

Fortunately, in Rosenberg's view, modern scholarship aided in such an enterprise because of "the scientific criticism of the text" of the Bible (Rosenberg, 1935b:603-608). This has enabled scholars to separate the truly noble elements of the gospels from the Jewish dross in which they are entwined. Here the culprits in the New Testament are Mark, Matthew and Paul who subverted all that was 
original in early Christianity by making it a Jewish religion (Rosenberg, 1935b:605).

Thus the myth of a suffering god has to be replaced by the more noble myths of Nordic origin. Yet, even though we may recognise echoes of our situation in works like the Edda, they are no more than echoes from a time past (Rosenberg, 1935b:219). Today "a new genius who will reveal the new Myth to us" is needed. Therefore we have a duty to prepare for this new revelation. This new message must be directed to "all those who have already broken inwardly with church belief, but have still not found their way to another Myth" (Rosenberg, 1935b:600-601).

Rosenberg's frequent mention of old Germanic works like the Edda and his appreciation for stories about ancient Nordic gods, led critics to ridicule the Mythus as a call for Germans to return to the worship of pre-Christian German gods, something he vigorously denied after the Mythus was first published in 1930 (Rosenberg, 1935b:5-18). Most critics, however, recognised that it was not Rosenberg's intent to reinvent "Wotanism" or any other ancient Nordic religion. Nevertheless they followed Levy in arguing "In practice, that the German youth is being trained to abandon Christ and to worship the god Wotan of Nordic mythology ..." (Levy, 1939:42).

In this way it was easy to make fun of Rosenberg as someone who wanted Germans to dress up in sheepskins and run naked in the woods. This image was quickly transferred to the English speaking world by writers like Fest, creating the impression that Rosenberg's work was beyond contempt (Fest, 1970:167-168).

Actually, as he pointed out in his forwards to later editions, Rosenberg believed that returning to the worship of ancient gods was the height of folly (Rosenberg, 1935b:5-7). Nevertheless, he thought Europeans could learn from the old Germanic and Norse myths by asking what message they originally conveyed to those who believed them. This message, he believed, was one of heroic values, honor, and virtue (Rosenberg, 1935b:115-116; 135-136).

When interpreting the meaning of ancient myths, Rosenberg employed a process known as "demythologizing". In the realm of New Testament studies this method was made famous by the theologian Bultmann (1884-1976), and is still used to interpret the New Testament in universities and theological seminaries. What Bultmann did was to assert that, because of the rise of modern science, people no longer believed in reports of miracles and similar wonders 
found in the Bible. Then he argued that, rather than destroying faith, this disbelief ought to be recognised and used to reinterpret the Bible (Bultmann, 1958; Jaspers \& Bultmann, 1958:57-71).

Thus, instead of taking the New Testament as a reliable account of the life of Jesus, like the orthodox Christian, Bultmann, argued, modern readers must learn to ask what stories about miraculous deeds were intended to communicate to their original hearers. In other words, they need to ask what the message behind the story is. In this way, Bultmann believed that he was restoring to modern people the power of the message of Jesus stripped of supernatural baggage. Miracle stories were simply ways of expressing the profound impact that Jesus' call to repentance and absolute obedience to God had on his hearers. Therefore, modern people should forget about the story and obey the message (Thiselton, 1992:280-282; 452462).

Similarly, Rosenberg believed one could strip away all the baggage that clouds our understanding of myths to recover the original intent of the story-teller, by asking what the cultural and historic settings for ancient myths was. In this way he engages in a form of demytheologising to produce a heroic history intended to provide modern people with examples of virtue that would inspire their daily lives (Rosenberg, 1935b:138-140). Thus the symbolism, and not the actual story, is what was important (Rosenberg, 1935b:105). As such, the role of myth was to inspire honour and creativity in the soul (Rosenberg, 1935b:143-144). Interestingly, the historian of religions, Eliade (1907-1986) understands the heroic element of myth in a similar way (Eliade, 1971:34-48).

Importantly, contrary to what many writers claim, Rosenberg strongly rejected monism (Rosenberg, 1935b:125-126). In doing so he argues that at their core, Judaism and Christianity are monistic (Rosenberg, 1935b:127-128). This, he suggests, leads paradoxically to the "polarity" absolutist beliefs in things like good and bad, true and error (Rosenberg, 1935b:125-127). Against such a "static" view he urges a "dynamic" vision of the world that recognises the continuous interaction and development (Rosenberg, 1935b:127). Rosenberg sees Protestantism, however, as divided between the "Jewish" impulse to monism and the "German desire for freedom" (Rosenberg, 1935b:128-129). Yet in the end, he argues, Protestants failed to free themselves from such beliefs, because Luther popularised the Old Testament as a "Christian book", thus making the break with Jewish monism impossible (Rosenberg, 1935b:129). 
Finally, it needs to be recognised that Rosenberg's neo-paganism borrowed from a rich tradition of German philosophical thought that was familiar to his readers. Thus, without mentioning them by name, he appropriates the ideas of Feuerbach (1804-1872) and Strauss (1808-1874) as interpreted by De Lagarde (1827-1891), and Nietzsche (1844-1900), who he does cite on these type of issue (Rosenberg, 1935b:37, 138, 237, 443, 454-456, 424, 530, 691-692).

To summarise, Rosenberg's new paganism can be described as follows: humans need to recognise that for the individual, there is only one life, this life, and that death is the end of personal existence. Ordinarily such recognition would make life meaningless, but this is not the case. Every human is linked to his/her descendents and passes on to them a genetic inheritance that can be improved or wasted. As Rosenberg puts it "Man is nothing in himself. He is personality only insofar as he is fitted intellectually and spiritually into an organic ancestral succession of thousands of generations." (Rosenberg, 1935b:634.)

Therefore, it is the duty of every individual to face life in the knowledge that while their death ends personal consciousness, their genetic inheritance creates a form of immortality by which they live on, both through their descendents and through the memory of their deeds. Life is thus a heroic challenge to overcome environmental constraints and triumph over adversity through the knowledge that the individual exists in community (Rosenberg, 1935b:187-189, 563566).

For him and his readers, the myths of the old Germanic gods captured this affirmation of life, while Christian and Jewish myths destroyed life by misdirecting the individual's attention to a life beyond this world and a God created in their own image. Therefore, he claimed that men and women must choose between commitment to a dynamic, life affirming religion arising out of a specific historical culture, or a death affirming religion that glorifies a tyrannical God. The choice was simple. Embrace a religion that expresses the dynamic genetic values of heroism and virtue or an alien one that glorifies a static world realm beyond this world. Either become a true human by discovering oneself or allow the Old Testament and the Christian tradition to destroy individual freedom and true humanity (Rosenberg, 1935b:73-82, 698-701). 


\section{Conclusion}

Rosenberg's version of Germanic religion was not the only alternative available to Germans of those days. Numerous variations of the themes he enunciated existed at the time. Yet, all affirmed the same basic values which called upon people to renounce the Christian tradition in favour of a dynamic, life affirming creed rooted in the German tradition that expressed the need for rebirth and a new beginning. To dismiss such beliefs as ephemeral, is to misunderstand the cultural milieu that gave birth to nazism and allow these and similar beliefs to fester today, because few people recognise their origins and potential for evil.

\section{List of references}

BARKAN, E. 1992. Retreat of scientific racism: changing concepts of race in Britain and the United States between the World Wars. Cambridge: Cambridge University Press.

BRACHER, K.D. 1969. Die deutsche Diktatur. Köln: Kiepenheuer \& Witsch.

BRACHER, K.D. 1970. The German dictatorship: the origins, structure and effects of National Socialism. Trans. by J. Steinberg. New York: Praeger.

BRANDENBURG, H-C. 1968. Die Geschichte der H.J. Hitler: Jugend Wege u Irrwege e Generation. Köln: Wissenschaft und Politik.

BULTMANN, R. 1958. Jesus Christ and mythology. New York: Scribner.

CHAMBERLAIN, H.S. 1899. Die Grundlagen des neunzehnten Jahrhunderts. München: Bruckmann.

CHAMBERLAIN, H.S. 1905. Arische Weltanschauung. Berlin: Bard \& Marquardt.

CHAMBERLAIN, H.S. 1911. Foundations of the nineteenth century. London: Lane.

CHESTERTON, C.K. 1934. Germany's national religion. London: Friends of Europe.

DE ROUGEMONT, D. 1998. Journal aus Deutschland, 1935-1936. Wien: Zsolnay.

DODD, M. 1940. Through embassy eyes. New York: Garden City.

DOSTOYEVSKY, F. 1995. The brothers Karamazov. Trans. by D. Fishelson. New York: Dramatists Play Service.

DUBOW, S. 1995. Scientific racism in modern South Africa. Cambridge: Cambridge University Press.

ELIADE, M. 1971. The myth of the eternal return; or, Cosmos and history. Princeton: Princeton University Press.

FEST, J.C. 1970. The face of the Third Reich: portraits of the Nazi leadership. New York: Pantheon.

FIELD, G.G. 1981. Evangelist of Race: The germanic vision of Houston Stewart Chamberlain. New York: Columbia University Press.

GILBERT, G.M. 1947. Nuremberg diary. New York: Farrar, Straus.

GITTA, S. 1995. Albert Speer: his battle with truth. New York: Knopf. 
GOEBBELS, J. 1987. Die Tagesbücher von Joseph Goebbels: samtliche Fragmente. Bande 1: 27.6.1924-31.12.1930. Ed. by E. Fröhlich. München: Institut für Zeitgeschichte.

GRIFFIN, R. 2007. Modernism and Fascism: the sense of a beginning under Mussolini and Hitler. Houndmills: Macmillan.

HANFSTAENGL, E. 1994. Hitler: the missing years. 2nd ed. New York: Arcade.

HEUSS, T. 1968. Hitlers Weg. 2. Ausg. Tübingen: Wunderlich.

HEXHAM, I. 2007. Inventing "Paganists": a close reading of Richard SteigmannGall's The Holy Reich. Journal of contemporary history, 42(1):59-78.

HITLER, A. 1940. Mein Kampf. München: Zentralverlag der NSDAP., Franz. Eher Nachfolger.

HITLER, A. 1941. Mein Kampf. Trans. by J. Chamberlain, et al. New York: Reynal \& Hitchcock.

HITLER, A. 1943. Birthday greetings to Alfred Rosenberg - a letter. Archives du Centre de Documentation, Juive Contemporaine, Document LXII, 9, Letter from Adolf Hitler to Alfred Rosenberg, (11.1.1943).

HÜFFMEIER, H. 1935. Evangelische Antwort auf Rosenbergs Mythus des 20. Jahrhunderts. Berlin: Kranz-Verlag.

HUTCHINSON, G.P. 1977. The Nazi ideology of Alfred Rosenberg. Oxford: Oxford University Press. (Unpublished Ph.D. thesis.)

JASPERS, K. \& BULTMANN, R.K. 1958. Myth and Christianity: an inquiry into the possibility of religion without myth. New York: Noonday.

KELLOG, M. 2005. The Russian roots of Nazism. Cambridge: Cambridge University Press.

KLEMPERER, V. 1995 Ich will Zeugnis ablegen bis zum Letzten: Tagebücher 1942-1945. Berlin: Aufbau-Verlag.

KNELLER, G.F. 1941. The educational philosophy of National Socialism. New Haven: Yale University Press.

LEVY, R. 1939. An introduction to current affair. Baltimore: Wallace.

LÖWITH, K. 1986. Mein Leben in Deutschland vor und nach 1933. Stuttgart: Metzler.

LUDECKE, K.G.W. 1937. I knew Hitler. New York: Scribner.

MOSSE, G.L. 1964. The crisis of German ideology: intellectual origins of the Third Reich. New York: Universal Library.

MOSSE, G.L. 1991. The nationalisation of the masses. Ithaca: Cornell University Press.

PETZOLD, J. 1983. Die Demagogie des Hitlerfaschismus. Frankfurt: Röderberg-Verlag.

POEWE, K. 2006. New religions and the Nazis. Oxford: Routledge.

ROSENBERG, A. 1935a. An die Dunkelmänner unserer Zeit. München: Hoheneichen-Verlag.

ROSENBERG, A. 1935b. Der Mythus des 20. Jahrhunderts. München: Hoheneichen Verlag.

SCHMITT, W., Hrg. 1937. Der Parteitag der Arbeit. München: Eher Verlag.

SPEER, A. 1970. Erinnerungen. Frankfurt: Ullstein.

STEIGMANN-GALL, R. 2003. The Holy Reich: Nazi conceptions of Christianity, 1919-1945. Cambridge: Cambridge University Press.

STRASSER, O. 1948. Hitler und ich. Konstanz: Asmus.

THISELTON, A.C. 1992. New horizons in hermeneutics. Grand Rapids: Zondervan. 
WRIGHT, J. 1974. "Above Parties": the political attitudes of the German Protestant Church leadership, 1918-1933. London: Oxford University Press.

\section{Key concepts:}

anti-Christian propaganda

Nazism

neo-paganism

new atheism

Kernbegrippe:

anti-Christelike propaganda

Nazisme

neo-paganisme

nuwe ateïsme 